\author{
Wafi Fhaid Alshammari \\ University of Ha'il, Saudi Arabia
}

\title{
TENSE/ASPECT MARKING IN ARABIC-BASED PIDGINS
}

Summary. The earliest stages of pidgin formation show a preference for analytic and morphologically reduced grammatical constructions relative to their lexifier or substrate languages, where the apparent morphological marking, if found, seems to be fossilized. Structural relations, therefore, are mostly expressed externally. Tense/aspect categories are marked through temporal adverbials or inferred from the context. Creole languages, however, are said to develop such categories through grammaticalization. This study examines tense/aspect marking in five Arabic-based pidgins: Juba Arabic, Turku Pidgin, Pidgin Madame, Romanian Pidgin Arabic, and Gulf Pidgin Arabic. Using Siegel's (2008) scale of morphological simplicity, from lexicality to grammaticality, this study concludes that tense/aspect marking is expressed lexically through temporal adverbials or inferred from the context in the earliest stages of Arabic-based pidgins, which only later-in stabilized pidgins-develops into grammaticalized markers when certain criteria are met.

Keywords: Arabic-based pidgins; tense; aspect; lexical markers.

\section{Introduction}

When heterogeneous speech communities come into contact and do not share a language in common, they utilize facilitative means to make their communications mutually intelligible. Pidgin languages arise through a process of targeting the lexicon of one of the groups, usually the superstrate language-'the lexifier'-and substrate languages, which also contribute to the creation of a communal language. Pidginization and the development of a pidgin language emerge within certain social upheavals from which result contact settings that put a premium on the development of such languages. In fact, long-term contact among such linguistically heterogeneous communities can result in an ongoing process of negotiation through accommodation. The evolving linguistic system can then develop into a community-wide, conventionalized solution. On the structural level, the formation of such a contact variety mostly proceeds in high variation, but within a specific configuration of reduction/simplification processes. Such processes are ongoing through various stages in the development of a communal language, notably jargon, pidgin, stabilized pidgin, expanded pidgin, and creole (see Mühlhäusler, 1986, 1997). 
Givón (1998) differentiates two types of communication in terms of structural, functional, and cognitive properties: pre-grammatical and grammatical communication. The former refers to the incipient, or unstable, pidgin, which relies heavily on augmented gestures and less complex one- or two-word utterances with a topic/comment pragmatic structure. Clements (2009, p. 2) suggests, "[F]requent repetition of certain patterns in discourse (i.e., in language use) is the basis of the sound-meaning mappings, pregrammatical structures, and ultimately the development of a grammar code." Contrary to the pre-grammatical code is the grammatical code which develops in a more complicated system, often involving tense/aspect markers (Clements, 2009). In their 1997 study of The Basic Variety, Klein and Perdue indicate that naturalistic adult second language learners go through a stage where tense/aspect markers replace temporal adverbials to express temporality. In pidgin formation, native speakers use simplified, and sometimes ungrammatical, ${ }^{1}$ forms to accommodate non-native speakers; nonnative speakers then incorporate these simplified forms as they create their own grammatical systems. Such interactions involve accommodation toward negotiated solutions where some mutually intelligible linguistic forms propagate. In these initial stages of forming and restructuring a communal language, verb forms are mostly fossilized/frozen, whereas tense/aspect marking is expressed externally through lexical tense/aspect markers or inferred contextually. This preponderance of analytic constructions helps the receiver to map transparent word-meaning in addition to being more detectable than bound morphemes. In other words, speakers of such contact varieties tend to favor the use of content morphemes over grammatical morphemes (Clements, 2014; Mühlhäusler, 1997).

There are various diagnostic features that distinguish pidgins from creoles, including tense/aspect marking (Bickerton, 1974; Labov, 1990; Smith, 2013). In creoles, tense/aspect markers are generally expressed by preverbal and adverbial elements (Muysken, 1981; Singler, 1990). However, auxiliaries, serial verbs, and verb suffixes might also serve as tense/aspect markers. Some

\footnotetext{
${ }^{1}$ By ungrammatical, I mean that the use of forms that are considered incorrect from the native Arabic speaker's perspective, such as using the $3^{\text {rd }}$ MascSgPres verb form to refer to a past action, instead of using the past verb form.
} 
scholars suggest that the transition from a pidgin to a creole necessitates the development of obligatory tense and aspect markers (Labov, 1990; Versteegh, 2014). Additionally, pidgins show a preponderance of morphological simplicity, i.e., preference of analytic constructions, relative to their lexifier or substrate languages (Holm, 1989; Siegel, 2008; Thomason \& Kaufmann, 1988; Voort, 1994). Structural relations that are expressed morphologically in other languages tend to be expressed lexically (e.g., the use of time adverbials rather than morphological tense/aspect markers to indicate temporal and aspectual relationships (Labov, 1990; Siegel, 2008). Siegel (2008) uses a scale of morphological simplicity, ranging from lexicality to grammaticality, as shown in (1).

(1) content item > grammatical word $>$ clitic > inflectional affix

The scale in (1) shows that each item on the right is more grammatical and less lexical. Basing his assumption on Hopper and Traugott (1993), Siegel (2008, p. 23) notes, "Lexicality is an absolute indicator of morphological simplicity, while increased grammaticality corresponds to greater complexity." Overall, the status of tense/aspect marking in Arabic-based pidgin has not been fully evaluated. Only some scattered comments are found in some studies, in addition to Versteegh's (2020) study on the temporal reference in two contemporary varieties of Arabic. Among the open questions are: To what extent do Arabic-based pidgins follow this dichotomy of lexical versus morphological tense/aspect marking?

In this study, therefore, I offer an overview of one diagnostic feature in Arabic-based pidgins, centering around tense/aspect marking in five Arabicbased pidgins, but with minimal attention to mood. Two of the Arabic-based pidgins examined here are stable pidgins: Juba Arabic (JA) and Turku Pidgin (TP), spoken in east Africa; three are pre-pidgins (alternatively: incipient pidgins): Pidgin Madame (PM), spoken in Lebanon, Romanian Pidgin Arabic (RPA), spoken formerly in Iraq, and Gulf Pidgin Arabic (GPA), spoken in Saudi Arabia. Then, I connect expressing notions of tense/aspect to the widely known diagnostic features of pidgin languages, which, thereby, enables us to perceive how tense/aspect is expressed in the early stages of pidgin formation. The data 
for the current study are drawn from previous research (e.g., from Avram, 2011; Manfredi \& Petrollino, 2013; Tosco, 1995 on JA and TP; from Bizri, 2009, 2010 on PM; Avram, 2010, 2011 on RPA; and from a corpus of fieldwork interviews conducted by the researcher between native Saudi Arabic speakers and foreign workers on GPA). ${ }^{2}$

This paper is structured as follows: Section 2 introduces pidgins, creoles, and their relationship. Section 3 presents background on tense/aspect marking in Arabic-the lexifier. Section 4 reviews tense/aspect marking in pidgin languages. Section 5 deals with the analysis of tense/aspect marking in Arabic-based pidgins. Section 6 provides implications of tense/aspect marking in Arabic-based pidgins. Finally, Section 7 concludes this paper with a recommendation for future research.

\section{Pidgins, Creoles, and Their Relationship}

Time to study pidgin and creole languages and scholars' interests towards these contact varieties was delayed because of the negative attitudes surrounding these contact varieties. Such contact varieties were neglected, stigmatized, and regarded as low-status and marginal rather than as fullfledged varieties. The development of linguistics and language studies presaged for understanding the dynamics of language and the interconnection between the individual and society, which consequently has allowed for dealing with different types of contact varieties, e.g., the speech of children, foreigners, aphasics, and others (Holm, 2004). Despite Hugo Schuchardt's publication of many articles and reviews on the subject in the second half of the nineteenth century, the study of pidgins and creoles did not evolve in the academic realm until the late 1950s and early 1960s (Holm, 1988; Thomason, 2008), as they raise the general awareness of language creation-or genesis (Ansaldo \& Matthews, 2007). Since that time, many linguists have developed interests in the study of pidgin and creole, as these linguistic systems are influenced by social forces and help explicate language acquisition and evolution (Holm, 2000).

\footnotetext{
2 I have maintained as much as possible the transcription and gloss of the original in examples in the literature.
} 
Even though the field of pidgin and creole studies has been established as an academic discipline for more than 50 years, linguists still debate the definitions of these contact varieties. According to Mufwene (1997), the term creole spread from Spanish into other European languages in the late sixteenth century and was used in France in 1590 as crollo. Arveiller (1963) identifies 1722 as the starting point for the use of créolles to refer to black slaves born in the West Indies (St. Christopher, today St. Kitts). Later, in the mid-nineteenth century, the term creole was coined to refer to people born in the colonies (Mufwene, 1997).

The etymon of the word pidgin is uncertain. Some linguists (e.g., Bakker, 1994; Baker \& Mühlhäusler, 1990), and the Oxford English Dictionary derive the term from the English word business as pronounced in Chinese Pidgin English. Holm (2000, p. 5), drawing a line between a creole and a pidgin, states, "[A creole] has a jargon or a pidgin in its ancestry; it is spoken natively by an entire speech community, often one whose ancestors were displaced geographically so that their ties with their original language and sociocultural identity were partly broken," whereas "[A pidgin is] a reduced language that results from extended contact between groups of people with no language in common." Some researchers (e.g., Sebba, 1997; Thomason \& Kaufman, 1988) have accepted three criteria for defining pidgins, namely, (a) that pidgins have no native speakers, (b) they are governed by convention, and (c) they are not mutually intelligible by speakers of their source languages (Sebba, 1997). However, the notion that creoles have native speakers whereas pidgins do not has been challenged (cf., inter alia, Mufwene, 1997; Muysken \& Smith, 1994; Singler, 1990, 1992). Mufwene (1997), for instance, declares that recent research disputes the role of children in creolization. In this sense, Singler (1996) indicates that adults are the innovators of Martinican and Haitian creoles. Mufwene (1997) argues that creolization is a social, not a structural, process. Mufwene's declaration suggests that absolute criteria defining pidgins and creoles in relation to other languages have not been established.

Arabic-based pidgins and creoles appear to be of particular interest because of the long history of Arabic, which created different types of language contact and language shift. When looking at the linguistic situation in the Arab world, we find various minorities with multilingual and multicultural ethnicities, 
beside the diglossic situation of Arabic manifested through the co-existence of MSA/Classical Arabic (High variety "H") and dialectal Arabic (Low variety "L") (Abd-el-Jawad, 1992; Al Wer, 2002). Additionally, multi-dialectal Arabic can be seen as another source of variation where regional dialects and social dialects vary according to different measures, including, but not limited to, Bedouin/sedentary or rural/urban dichotomy. Another source of complication in the situation of Arabic is the emerging work-driven pidgins, which evolve due to the need for communication, in addition to the social gap among the cocreators of such contact variety.

\section{Tense/Aspect Marking in Arabic-The Lexifier}

While there are various lexifiers for the Arabic-based pidgins examined here, this logically leads to the conclusion that tense/aspect marking varies across Arabic varieties. This section briefly outlines the concepts related to tense/aspect marking, their interpretation, and relevance to Arabic varieties, with various degrees of variability.

Comrie (1985, p. 1) defines tense from a syntactic perspective as "a grammaticalized expression of location in time." Mowarin (2008), however, conceives of tense as a linguistic universal when viewed in the context of a semantic notion of time. He declares that while most European languages have grammaticalized tense, African languages tend to lack it and, thus, are called tenseless languages (grammatically). He presents a cross-linguistic typology of tense and divides languages into three subsets where tense is viewed as a grammatical concept: (a) absolute tense, "where tense is viewed in terms of the binary opposition of past/non-past, and future/non-future," such as in English, (b) relative tense, "where the reference for location of a situation is context and not the present moment," such as in Russian, Classical Arabic, and Latin, and (c) tenseless languages, where "tense is not grammaticalized in these languages because there is no grammatical difference between non-past and past. Lexicalization is used to express time reference with time adverbials," as in many African languages (Mowarin, 2008, p. 74).

Aspect conveys how the speaker views the situation, for example, in progress, in a certain state, or as an action (Comrie, 1985). The term expresses 
"the internal temporal consistency of an event or state" (Bakker et al., 1994, p. 247). Types of aspect are the perfective, imperfective, durative, habitual, iterative, and progressive. According to Bache (1985), the perfective aspect concerns an external focus on the situation. While the speaker views the perfective in a situation from the outside as a complete process, the imperfective is viewed as an in-progress situation.

There are disagreements among Arabic linguists regarding the semantic basis of the Classical Arabic/MSA verbal system as to whether the opposition represents past/non-past tense, perfective/imperfective aspect, both tense and aspect combined, or something else (i.e., the opposition between verbs like kataba 'he wrote' and jaktubu 'he writes.') In fact, this type of disagreement is also present among early and medieval Arab grammarians (Bahloul, 2008). I detail this division among linguists based on the examples in (2) and (3).

(2) katab-a (Perfective) write-perf.-3MascSg

- He wrote.

(3) j-a-ktub-u (Imperfective)

3Masc-imperf.-write-Sg

- He writes/is writing.

Proponents of the aspect view (e.g., Al-Mansouri, 2002; Beeston, 1970) suggest that the opposition between verbs in (2) and (3) is completed versus uncompleted actions, where tense is contextually determined. The proponents of the tense view (e.g., Aartun, 1963) indicate that the difference between the two verbal forms in (2) and (3) is based solely on past and non-past, respectively. Comrie (1976) is among combined-tense-and-aspect proponents who suggest that Arabic is a language with combined tense/aspect oppositions and believe that the distinction between imperfective and perfective signals both aspect and relative tense. Comrie's reasoning is that there is a lack of contextual factors in the opposition. Finally, neither-tense-nor-aspect proponents indicate that the opposition between verbal forms in (2) and (3) is anteriority versus simultaneity, respectively, because the value of the opposition is relational. According to Bahloul (2008), the verbal forms in (2) and (3) have no aspect since aspect requires the existence of a tense. 
Moreover, tense is not admitted because the verb jaktubu can have both present and past time reference.

\section{Tense/Aspect Marking in Pidgin Languages}

The study of tense/aspect occupies an important position in the linguistic descriptions of pidgin and creole languages due to their inherent structural similarities, regardless of the lexifier or substrate languages influencing their emergence. Additionally, Bickerton's (1974) proposal that creole languages develop three aspect markers-past, nonpunctual, and irrealis-stimulated heightened debates among creolists as to whether this proposal applies universally to creole languages. As for pidgins, variation is ubiquitously inherent (Bakker, 1994; Holm, 2000; Sebba, 1997; Siegel, 2008); they show a preponderance of analytic and morphologically reduced grammatical constructions relative to their lexifier or substrate languages where the apparent morphological structure, if found, seems to be fossilized (Foley, 1988; Holm, 1989; Thomason \& Kaufmann, 1988; Voort, 1994). Structural relations are either not expressed at all, for example, as the absence of complementizers to indicate subordination, or expressed through lexical items, such as adverbs that indicate temporal and aspectual relations. A lack of tense/aspect categories is not uncommon in pidgins (Labov, 1990). Nevertheless, adverbial expressions may suffice to express tense/aspect, although there are some exceptions, such as expanded pidgins (e.g., Tok Pisin and West African English; Bakker, 1994).

Tense/aspect markers can develop from different parts of speech (e.g., copulas, adverbs, and verbs (Clements, 2014)). Time is optionally indicated through context or adverbials (e.g., yesterday, now, tomorrow, and later, whereas mood can be expressed by words such as maybe; Parkvall \& Bakker, 2013; Sebba, 1997; Velupillai, 2015). Such pidgins include Pidgin Fijian (e.g., malua 'later,' liu 'before,' mataka 'tomorrow,' and nikua 'now'; Sebba, 1997), Chinese Pidgin English and Hottentot Pidgin Dutch (Bakker, 1994), Melanesian Pidgin English (Bakker, 1994), and Hawaiian Pidgin English (e.g., olden time, young time, small boy time, etc.; Labov, 1990). Labov (1990), commenting on the grammar of Osan, a Japanese speaker of Hawaiian Pidgin English, indicates 
that there are no inflections, and verbs appear in their invariant stem form. Moreover, other grammatical categories are sharply reduced.

If the lexifier contains inflectional morphemes, then one inflected form is mostly used with all persons, tenses, and genders, or the bare stem is used to refer to all other forms. When tense can be inferred contextually, there is no overt tense marking (Sebba, 1997). Velupillai (2015) compares the existence of tense in 37 pidgin languages with 318 non-pidgin languages and finds that tense exists in only $32.4 \%$ of pidgins, whereas $67.6 \%$ of pidgins do not mark tense morphologically. On the other hand, from the non-pidgins examined, $75.8 \%$ exhibit tense, whereas $24.2 \%$ show no tense. Velupillai (2015) concludes that it is common for pidgin languages to lack tense. Another example is Chinuk Wawa, which is a pidgin that lacks tense whereby context or adverbials usually express temporal relations, as shown (Grant, 2013, p. 153).

(4) náyka ískam kəním Chinuk Wawa (Pidgin (Chinook-lexified): Canada, USA) 1SG take canoe

- I took/am taking/will take the canoe.

In example (4), it is difficult to determine the temporal reading of the verb with no access to the context in which the verb was used (Velupillai, 2015). Labov (1990, p. 16) states,

\begin{abstract}
One of the most striking characteristics of most pidgins is that they have no tense marker and therefore no grammatical category of tense. By that, I mean not only the absence of the inflectional ending, English -ed or French -ais, but also the absence of any obligatory element in the verb phrases to identify the time reference of each predication. Past, present, and future are unmarked. Time relations are expressed by optional adverbial phrases. ${ }^{3}$
\end{abstract}

The simple past and present are normally unmarked in the Portuguese-based pidgin spoken in Guinea. For example, I sibi can mean 'he knew' or 'he knows' (Labov, 1990). Similarly, according to Fayer (1990, pp. 188-189), Nigerian Pidgin English used in the eighteenth century shows that $93 \%$ of the verbs referring to past actions or states are unmarked. However, adverbials occur

\footnotetext{
${ }^{3}$ Bolding is original to Labov 1990.
} 
mostly at the beginning of sentences, whereby most other events follow from this initial temporal reference point. An example of this is so when it is used in successive sentences with the meaning of as a result or then to indicate temporal sequence. Few verbs occur in past tense forms. However, closer examination reveals that such forms are used in the same constructions where the base form of other verbs is used.

There are, however, a number of pidgin languages that do have tense; sometimes, affixes are used to indicate tense, like the Yimas-Arafundi Pidgin, spoken in Papua New Guinea, as shown in (5).

(5) aykum mariak-nan (Yimas-Arafundi Pidgin: Papua New Guinea) woman talk-NFUT (Foley, 2013, p. 108)

- The woman spoke/is speaking.

Although Bakker (1994, p. 38) confesses that "not enough research has been done on the lexical expressions of aspect in pidgins," he indicates that aspct is often lost, and sometimes the word finish seems to refer to the perfective aspect, as used in Nauru Pidgin English. Sebba (1997) attributes these processes to native speakers' simplification-often called foreigner talk. On the other hand, non-native speakers incorporate these simplified forms into their input, as they construct their own grammatical system. Klein and Perdue (1997) developed what they call the Basic Variety model (BV) within the European Science Foundation Project; this model proposes a developmental stage of language acquisition by adult immigrants. Their study centers around how learners map the linguistic input they have onto their early communicative situations. The study deals with strategies for learning linguistic structures experienced by learners of German, French, English, Dutch, and Italian. Versteegh (2018) admits that learning processes found in the early $L 2$ acquisition proposed in the BV and pidginization bring insights into the commonalities of these two learning settings. In the advancement of the BV, Benazzo (2003) and Benazzo and Starren (2007) propose a rudimentary form of communication they call a "pre-Basic Variety" stage, which they distinguish from the $\mathrm{BV}$ in that no verbs are used, except for fossilized forms. Utterances are mostly nominals and adverbials, with more concentration on topic/focus structures (Benazzo \& Starren, 2007). In contrast, 
the BV verbs start to develop but appear to be uninflected. In a later stage, morphological devices develop with the post-Basic Variety. One reason is that some aspectual distinctions remain ambiguous (e.g., perfect and progressive; see Versteegh, 2018 for further details on stages in the acquisition of temporal adverbs). Temporal and aspectual readings are not expressed morphologically, but events are expressed through temporal expressions through pragmatic devices. The present time is considered the default.

Investigating two BVs of Arabic, namely Gulf Pidgin Arabic and Pidgin Madame, Versteegh (2018) indicates that these varieties do not exhibit any grammatical markers to express tense and aspect notions, but they rely heavily on contextual inferences or pragmatic principles, such as the principle of natural order. In Pidgin Madame, for instance, temporal contextualizers are used to indicate such notions, for example, baddēm 'then' (< Arabic ba'dēn 'afterwards') is used for futurity, 'abel (< Arabic 'abl 'before') and awwäl (< Arabic 'awwal 'first') are used for the past reference, and hälla (< Arabic halla' 'now') is used to highlight the present tense. The verbal forms used are uninflected, and they are derived from a variety of verbal forms, such as imperative, $2^{\text {nd }}$ MascSg and $3^{\text {rd }}$ MascSg imperfective verb forms. Versteegh (2018) offers a list of several temporal adverbs taken from Bizri's (2010) data on Pidgin Madame, which, he considers, index features of the pre-Basic and Basic Variety.

\section{Tense/Aspect Marking in Arabic-Based Pidgins}

The present study considers Juba Arabic (JA), Turku Pidgin (TP), Pidgin Madame (PM), Romanian Pidgin Arabic (RPA), and Gulf Pidgin Arabic (GPA) and compares their tense/aspect marking systems to the diagnostic feature distinguishing pidgins from creoles, i.e., grammatical simplicity as compared to the development of obligatory tense/aspect markers (Labov, 1990; Versteegh, 2014). Detectability as a cognitive factor needs to account for whether the ways tense/aspect are marked are interpretatively useful in understanding the development of tense/aspect in Arabic-based pidgins. This section briefly introduces each contact variety before moving to the analysis of tense/aspect. 


\section{Juba Arabic}

$\mathrm{JA}$ is a variety spoken in southern Sudan and classified as a pidgin for some speakers, but a creole for others (Avram, 2011; Avram, 2020; Miller, 2003). Tosco (1995) classifies JA as a stable pidgin. The lexifier of this contact variety is Sudanese Arabic, with some input from Egyptian Arabic and Western Sudanic dialects (Avram, 2020). It was established as a military pidgin in camps of the Egyptian-British re-conquest in southern Sudan in early 1900 . The soldiers who joined these camps were the founders of JA. Later on, JA spread as a vernacular language to the urban and military centers, as it became the native language for urban dwellers as a result of heterogeneity, inter-ethnic marriages, and urbanization (Mahmud, 1982; Miller, 2002). Now, JA is spoken as a native language for approximately $47 \%$ of the population of Juba, the capital city of South Sudan, and as a second or third language by the majority of the population (Avram, 2020; Manfredi, 2017).

Tosco (1995) proposes that JA exhibits some features of creole languages, such as preverbal markers that are used to express tense/aspect. There are three overt preverbal markers in JA: anterior kan 'was', irrealis bi-, and nonpunctual ge (Manfredi \& Petrollino, 2013; Tosco, 1995). Also, habitual can be marked by ge or $\mathrm{Bi}^{-}$, according to their +/- irrealis character. Bi- needs to be followed by the dummy verb kun 'be' when used with nominal predicates (Tosco, 1995). Examples are shown below.

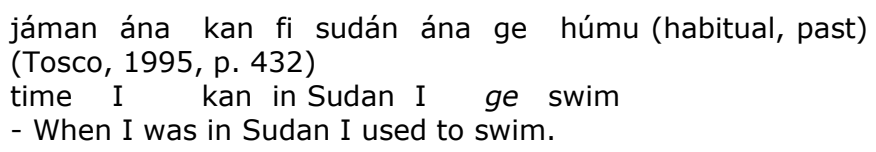

The preverbal marker kan in example (6) functions as anterior. It derives from the Arabic perfective kān 'he was.' It can co-occur with ge and bi, as shown in examples (7) and (8).

kan ana ge stákal fi kartúm (anterior, progressive)

ANT 1SG PROG work in Khartoum

(Manfredi \& Petrollino, 2013, p. 59)

- I used to work in Khartoum.

(8) kan ma šílu ána fi jibtália kan ána bi mútu (Manfredi \& Petrollino, 2013, p. 195) 
if NEG carry1SG in hospital ANT 1SG IRR die

- If I had not been carried to the hospital, I would have died.

Example (7) shows that kan is used with ge, in addition to the motion verb stákal 'work,' to indicate anterior progressive. Example (8), however, shows that kan comes with be- to indicate counterfactual conditional. The etymon of the preverbal particle $b i$ - is the imperfective $b i-$, used in some Arabic dialects, including Egyptian and Sudanic dialects. Mahmud (1979, p. 49) fails to account for $b i-$, as he states, " $b i$ cannot be linked etymologically to any verb in Sudanese Arabic, nor is it used in Standard written or Classical Arabic." I propose that $b i-$, similar to dialectal Arabic, comes from the verb jáb.ya 'he wants' (stressed on the first syllable), which has been reduced phonetically in some Arabic dialects to function as a future marker, such as Najdi Arabic jábi 'he wants' (see Owens, 2018 for further views and details on the historical origin of $b i$-in Arabic dialects). The occurrence of $b i$ - is mostly associated with irrealis. It may express future, counterfactual, and conditional meaning. Below are shown examples of bi- and ge.

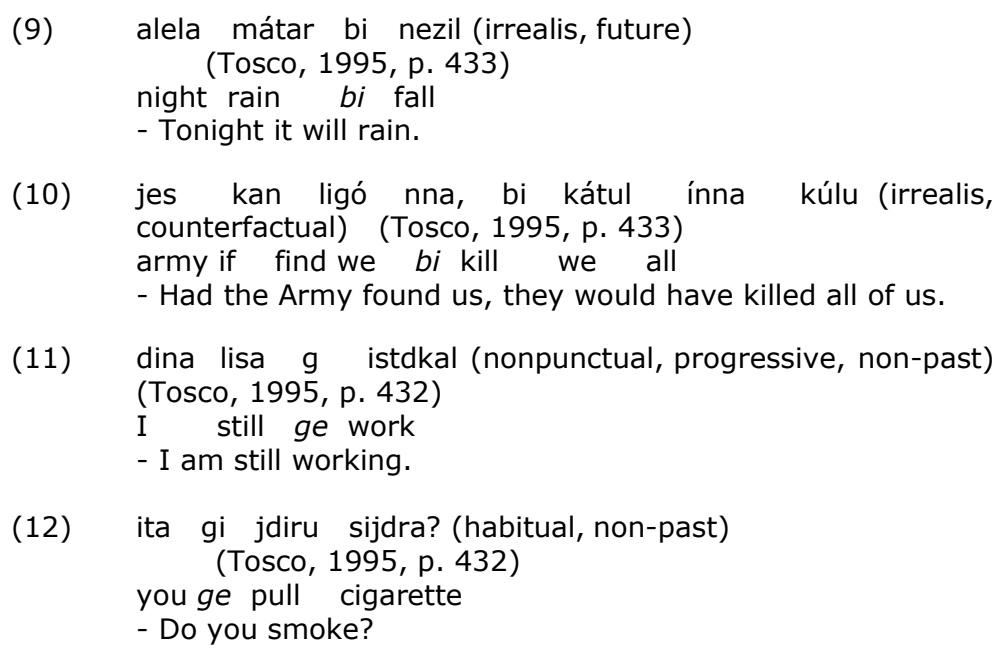

Tosco (1995) proposes that $b i$ - is undergoing change toward potential habitual actions, whereas ge is heading towards actual actions. Also, reduplicated verbs seem to force the notion of progressiveness, as shown in (13).

$$
\begin{aligned}
& \text { bágara de ge mútu-mútu (nonpunctual, progressive, } \\
& \text { non-past) }
\end{aligned}
$$


cow Dem TMA die-die

(Miller, 2003, p. 296)

- The cows are dying one after the other

JA and Ki-Nubi Arabic creole share the three basic verbal markers-ge, bi, and kan-although Tosco (1995) views the functions of bi and ge to be different in the two contact varieties. Naess (2008) suggests that ge and bi underwent grammaticalization in JA as they function as aspectual markers. While she does not elaborate on how these particles were grammaticalized, Mahmud (1979) links ge semantically to the word gaSad 'sat,' which is used in northern varieties of Sudanese Arabic both as a verb lexically and a progressive aspect marker inflectionally. He adds that words like gaid, gad, gud are phonetically reduced allomorphs of gaEd. Mahmud (1979, p. 48) suggests that ge has expanded its functional scope in JA; in other words, it marks "every aspectual subcategory: perfective, perfect, copula, durative, progressive, habitual, future, imperative, conditional, etc."

\section{Turku Pidgin}

TP is a pidginized variety formerly used in Chad-Niger area, which was established to unify a group of soldiers and followers of Rabeh, who established an ephemeral empire in Chad when clashes emerged between traders of Bahr Al Ghazal and the Turkish-Egyptian government in the late half of the nineteenth century. The etymon of Turku comes from the Arabic word turk turuk for 'Turkish' as it is used by Chadians to refer to those who come from Sudan regardless of their ethnicity. TP, which Rabeh's army established as a means of communication for the foreign soldiers and other African groups, achieved some degrees of stabilization (Tosco \& Owens, 1993). Additionally, TP is used as a trade pidgin in central Africa and northern Cameroon (Miller, 2003). The source languages of TP include Sara-Bagirmi languages, Sango, Fulfulde, Hausa, or Kanuri, and Western Sudanic Arabic (Avram, 2019). Unlike Ki-Nubi and Juba Arabic, TP did not undergo grammatical expansion. Some scholars believe that TP does not exist today; rather, it is an extinct variety. Miller (2003, p. 24), for instance, believes, "[N]o present-day Turku variety in Chad or central Africa seems to exist, at least not under this label, and we do 
not have a detailed description of present-day Chadian Pidgin Arabic."

TP has two preverbal markers: $b$ - and gahed, where the former is prefixed to the verb, and the latter corresponds to the preverbal ge found in JA. $B$ - functions as a habitual and future marker. The preverbal gahed expresses progressiveness. Verbs are mostly uninflected but derived from Arabic imperative verb forms. Examples are shown below.

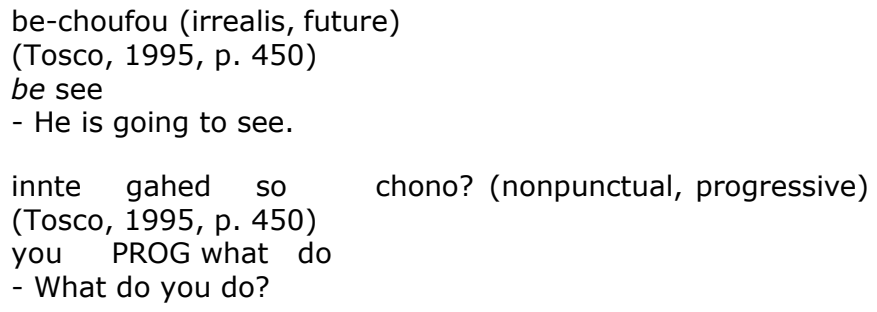

\section{Pidgin Madame}

PM is a contact variety spoken in Lebanon between Sri Lankan housekeepers whose native language is Sinhala and their Arab employers. It developed in a contact situation where only two speech communities were involved. The linguistic situation of PM, nonetheless, is different from what has been proposed regarding a pidgin development where the linguistic context would probably involve at least three languages (Holm, 2000; Wardhaugh, 2010; Whinnom, 1971). This, however, does not exclude PM from being a pidgin, as we find other similar cases of language contact that developed from only two speech communities, such as Pidgin Delaware (Goddard, 1996).

Bizri (2010) suggests that PM, unlike its lexifier-Lebanese Arabic (LA) -is genderless. Plurality is expressed lexically using terms such as kello 'all'; PM lacks relative pronouns; numerals are used in their 'count' forms. Moreover, tense/aspect marking is absent. Nevertheless, temporal adverbs, such as before and after, are used to denote tense. Bizri (2010) argues that frequency is a crucial factor determining the selection of the $2^{\text {nd }}$ and $3^{\text {rd }}$ feminine forms of the verb, due to the high frequency of female interactions. She (2009) states that modal particles are used to modify verbs. Time and progressiveness of action are inferred from the context or indicated by adverbs, or by a set of preverbal particles, taken from the lexifier. In 
addition to the particle pi (< LA $f i$ 'copula/existential there is'), kalas (< LA xala: $s^{\varsigma}$ 'it is finished/stop') is also used to denote the perfective aspect. Additionally, badde (< LA baddi 'I want') is grammaticalized to (volition, intention) + the first personal suffix -e 'me, my,' indicating that the subject is or was about to start the action (Bizri, 2009). Examples are shown below.

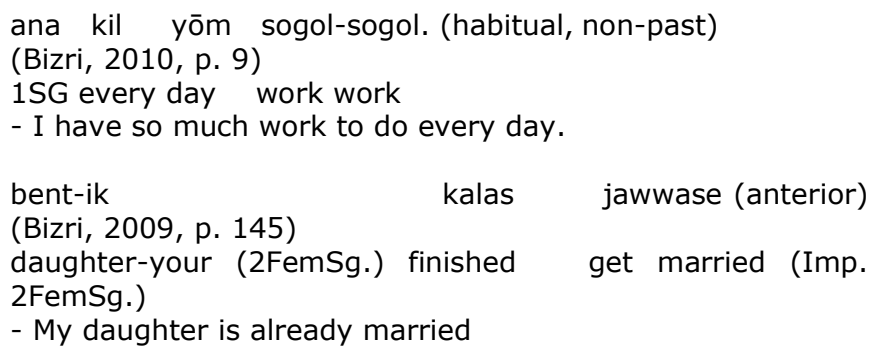

The reduplicated verb used in (16), sogol 'work,' is originally a verbal noun in Arabic, which does not carry any tense/aspect marker. The reduplicated verb in (13) of JA, however, hints at the progressiveness of the action. The habitual aspect of the verbal notion in PM is forced via the adverbial kil yōm 'every day'. Moreover, kalas (Arabic > xala: $\mathbf{S}^{\varsigma}$ 'it is finished/stop') 'finishing' is used to indicate anterior, as shown in (17). PM shows extensive use of Arabic feminine imperatives to express verbal notions. This is due to the high-frequency imperative verb form used in work-related interaction. Examples of feminine imperative forms are shown below.

$$
\begin{array}{lll}
\text { badde rûyi } \quad \text { badde sûpi } & \text { sûra } \\
\text { (Bizri, 2009, p. 145) } & & \\
\text { I want go(imp.fs) I want } & \text { see(imp.fs) } & \text { picture } \\
\text { - I want to see the picture. } & &
\end{array}
$$

The pseudo verb bidd- 'to want' comes from some Arabic dialects, especially Levantine dialects; however, the etymon of the Levantine bidd-/badd- is somewhat unclear. It may have come from bi-widdi 'on my desire/I want'. Moreover, PM extended imperative verb forms to other forms of verbs that are not commonly used in ordering someone, as shown below.

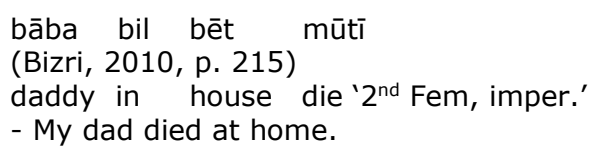


The verb in (19) mūtī 'you die, Imper., fem.' is used in the feminine singular imperative. Tense is inferred only contextually, and there is no indication of any overt tense/aspect markers.

\section{Romanian Pidgin Arabic}

RPA is a contact variety formerly spoken among Romanians, Egyptians, and Iraqi Arabic speakers working in oil camps in various locations in Iraq. Like Pidgin Madame, RPA is a two-way contact history-Romanian and Arabic. Romanians outrank both Egyptians and Iraqis in number, as they constitute two-thirds of the speech community. However, due to crew leaves, rotations, and replacements within the Romanian speech community, newcomers pick up the pidgin from the formers (i.e., approximations of approximations). This pidgin was disrupted and became extinct after the Gulf war in 1990, as Romanian speakers withdrew from the area (Avram, 2010, 2020). Tosco and Manfredi (2013) propose that the linguistic features of this contact variety make it a pre-pidgin contact variety.

RPA shows no overt marking of tense and aspect markers. Temporal and aspectual meanings are inferred contextually; also, time adverbials express such notions. Here, in RPA, the imperative verb form is used, but the context indicates that the speaker is referring to the past, as shown below.

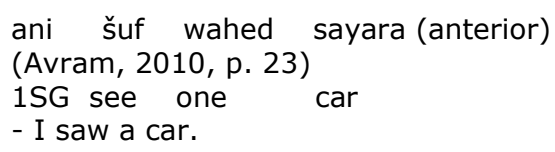

Not just imperative verb forms are used to express a verbal notion, as shown in (20), but so also are verbal nouns. The word kulu 'all' turns into an adverb meaning 'completely, totally' when reduplicated (e.g., kulu-kulu). This construction also facilitates the perfective aspect of the tense, as shown below.

(21) Halas šogol kulu-kulu (anterior)

(Avram, 2011, p. 242)

finish work all all

- [I] have finished my work completely. 
RPA is similar to GPA in that words such as awwal 'first' and ba:de:n 'later' are used to express anterior and future, respectively, as shown below.

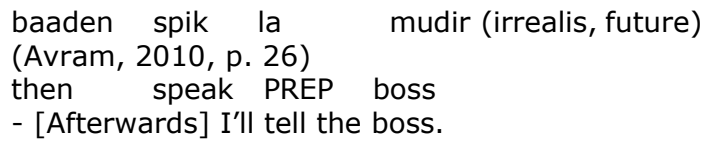

\section{Gulf Pidgin Arabic ${ }^{4}$}

GPA, which is just over fifty years old, is an Arabic-based pidgin in Arab Gulf countries used by foreign workers (FWs) who mostly come from South Asia, having diverse native languages, such as Hindi, Urdu, Bengali, Pashtu, Malayalam, Panjabi, Tagalog, Indonesian, Nepalese, Tamil, Sinhalese, and others, spoken between FWs and native Arabic speakers (Almoaily, 2012; Alshammari, 2018; Bakir, 2010). The emergence of GPA can be ascribed to the arrival of an expatriate labor force to the Gulf Cooperation Council countries. Here, I look at the variety of GPA spoken in Saudi Arabia since there are several varieties of GPA based on different Arabic lexifiers (Avram, 2020; Versteegh, 2020). Even though many scholars consider this variety incipient pidgin (Alghamdi, 2014; Alshammari, 2018; Naess, 2008), it is undergoing conventionalization in terms of verbal and pronominal form selection (Alshammari, 2018).

Many linguists (Alshammari, 2018; Bakir, 2010; Naess, 2008) agree that verbs in GPA come from various sources (i.e., verbs mostly come from verbal nouns, imperative, and imperfective and that the most salient forms are verbal forms, with some variations. According to Bakir (2010), GPA speakers mostly use one form of the verb where there is no morphological marking to express tense/aspect, voice, or agreement in gender, number, or person. Alshammari (2018) finds that verbal nouns, imperative verbs, and the $3^{\text {rd }} \mathrm{MscSg}$ imperfective verb forms are the most frequently used verbal forms for both native Saudi Arabic speakers and FWs. The apparent morphological markings of tense/aspect notions are mostly fossilized.

\footnotetext{
${ }^{4}$ All of the examples in this section are taken from the corpus of fieldwork interviews conducted by the researcher between native Saudi Arabic speakers and foreign workers.
} 
However, interlocutors rely heavily on the context to interpret the tense intended or use temporal adverbials, as shown below.

$$
\begin{aligned}
& \text { Ju:f awwal sau:djja fi: kwajjis } \\
& \text { look before Saudi Cop. good } \\
& \text { - Look, Saudi Arabia was good. }
\end{aligned}
$$

$$
\begin{aligned}
& \text { ma:lu:m madrasah awwal hina:k } \\
& \text { known school first there } \\
& \text { - I learned at school, there. } \\
& \text { Pana jidzi fi: Juyul ha:da fi: sa'u:djja } \\
& \text { I come-3rdMascSgPres Cop. work this Cop. Saudi } \\
& \text { - I came and worked here in Saudi Arabia. }
\end{aligned}
$$

The examples in (23) and (24) show that anterior is expressed using the time adverbial awwal 'before'. The word awwal 'before' which originates from Arabic is also borrowed into Urdu with the same meaning. In example (25), however, anterior can be inferred contextually. As noted, other forms such as verbal nouns, imperative verbs, or borrowed verbs are also used to denote verbal notion in GPA, as shown below.

$$
\begin{aligned}
& \text { maka:n ta:ni ma fi: ru:h } \\
& \text { place second Neg. EX go-imper. } \\
& \text { - I do not go to any other place } \\
& \text { Panta la:zim fi:l kullu Jai } \\
& \text { you necessary take every thing } \\
& \text { - You should take everything. }
\end{aligned}
$$

The lexifier of GPA from which the interviews were collected-Najdi Arabicforms the two-and-three consonantal-root imperatives differently than do other Arabic dialects (e.g., fil 'you take, imper.', rif 'you go, imper.', gil 'you say, imper.' and wadd 'you take to/deliver, imper'). Nevertheless, such forms of imperatives are not transferred into GPA, as shown in examples (26) and (27), but other forms used in other Arabic dialects which contain long vowels, e.g., ru:h (< Arabic ru: $\hbar$ 'you go, Imper.') 'go,' and fi:l (< Arabic fi:l 'you take, Imper.') 'take,' respectively. I propose that these forms were selected because they are more easily detectable than their Najdi Arabic counterparts. That is, long vowels are more readily detectable than their short-vowel counterparts. More examples of verbal nouns, which are used in GPA to express the verbal notion, are shown below. 


$$
\begin{aligned}
& \text { e:f Panta akil hina kull yo:m } \\
& \text { what you eating here every day }
\end{aligned}
$$

- What do you eat here every day?

Pana fi: ta:ni kala:m ke:rla

I Cop. second speech Kerala

- I speak Another language, Kerala.

$$
\begin{aligned}
& \text { ke:rla sawa sawa fi: girgir } \\
& \text { Kerala with with Cop. speak } \\
& \text { - I speak with people from Kerala. }
\end{aligned}
$$

In examples (28) and (29), the verbal notion is expressed through the verbal nouns, akil 'eating' and kala:m 'speech' respectively, where kull yo:m 'every day' in (28) indexes habitual. In example (30), the verbal notion is expressed through the borrowed verb girgir 'speak/talk, which seems to originate from substrate languages. Aspect markers are absent in GPA but are discernable contextually or expressed through time adverbials. For instance, alhi:n (< Arabic alhi:n 'now') 'now' is used to indicate the progressive or habitual aspect and kala:s (< Arabic xala:s ${ }^{\varsigma}$ 'finishing') 'finished/done' is used postverbally to communicate the perfect/ completive aspect, as shown in examples (31) and (32).

$$
\begin{aligned}
& \text { alhi:n fi: Juyul aba:jah } \\
& \text { now Cop. work Abaya } \\
& \text { - I work in Abayas. }
\end{aligned}
$$

The verbal notion in example (31) is expressed through the noun fuyul 'work,' where the habitual aspect is expressed lexically via the time adverbial alhi:n 'now.' Another word, ala tu:l (< Arabic Sala t'u:l 'on length/regularly') 'Prog.' is used to express the progressive or habitual, as shown.

$$
\begin{aligned}
& \text { ala tu:l fuyul hina } \\
& \text { on length work here } \\
& \text { - I always work here. }
\end{aligned}
$$

Even though the word kala:s (< Arabic xala:s' 'finishing') 'finished/done' comes from Arabic, as shown in example (33), it is also found in Pashto in the sense of 'finished' (khlaas); Bengali has the word khalash, meaning 'release; acquittal; liberation,' and the phrase khalash hoyegache means it is done (e.g., a job or a task). So, substrate languages could have influenced the selection of kala:s. It is used in GPA to indicate anterior. 
(33)

$$
\begin{aligned}
& \text { tadzrubah xala:s Pana alhi:n banna } \\
& \text { experience finishing I } \quad \text { now construction worker } \\
& \text { - I finished training and now I am a construction worker }
\end{aligned}
$$

Modals found in the lexifier-Arabic-have been exploited in GPA through the process of grammaticalization to indicate irrealis, e.g., possibility, necessity, and futurity. Futurity is expressed through the $3^{\text {rd }}$ MascSgPres verb form jabya 'he wants,' which has been extended to function as a future marker, beside its lexical meaning. The form jabya (< Arabic jabya 'he wants') 'Fut.' is an invariable preverbal marker that comes with all persons, genders, and numbers, as shown below.

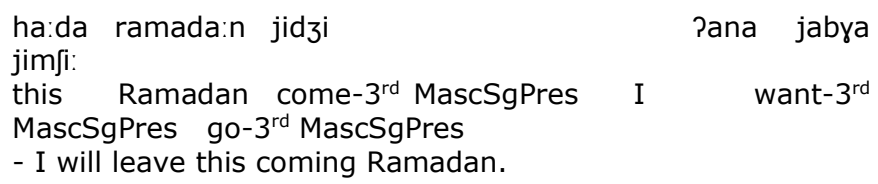

Futurity can also be expressed using ba:de:n 'then, later'. It is also used to index sequential actions, such as after that, as shown in (35).

$$
\begin{aligned}
& \text { ba:de:n jasa:l dzawa:b } \\
& \text { later ask-3rdMascSgPres answer } \\
& \text { - Then, they will ask him and he will answer. }
\end{aligned}
$$

A similar word to ba:de:n (< Arabic basde:n 'later') 'then, later' found in Urdu is baad mein, with the same meaning. Baad mein was borrowed from the Arabic word basdama 'after that' to Persian, which, in turn, was borrowed from Persian to Urdu (Wordinn Urdu; UrduWord.com). For possibility, the word mumkin 'possible' and for necessity the word la:zim 'obligatory' are used in GPA, as shown below.

mumkin ha:da Jahar a:xir jabya ru:h possible this month end want- $3^{\text {rd }}$ MascSgPres go.imper. - I may leave at the end of this month.

$$
\begin{aligned}
& \text { kullu jo:m la:zim kallam } \\
& \text { every day necessary call-3 }{ }^{\text {rd }} \text { MascSgPas } \\
& \text { - I should call them every day. }
\end{aligned}
$$

Many scholars suggest that the particle $\mathrm{fi}$ 'in/there is' has many functions, including as tense/aspect markers. Naess (2008), for instance, proposes that 
the $f i$ 'in/there is' is sometimes used preverbally to express progressiveness in GPA. Bakir (2010) and Al-Azraqi (2020) view fi as having multiple functions: as a preposition, an existential predicate, and a predication marker in copulative and verbal sentences, as shown in the following examples, respectively.

$$
\begin{aligned}
& \text { lakin awwal ana fii kuweit yištigil } \\
& \text { (Bakir, 2014, p. 416) } \\
& \text { but before } 1^{\text {st }} \text { in Kuwait work } \\
& \text { - But before, I worked in Kuwait. }
\end{aligned}
$$

fii nafar masri ijlis daakil makbas
(Bakir, 2014, p. 418)
EX person Egyptian sit inside bakery
- There was an Egyptian who used to sit inside the bakery.

$\begin{array}{llll}\text { ana fii maskiin sah walla laa } \\ \text { 1SG PM poor } & \text { right or } & \text { no } \\ \text { - I am a poor fellow, right? } & \end{array}$

\section{Implications of Tense/Aspect Marking in Arabic-Based Pidgins}

In the early stages of pidgin formation, interlocutors endeavor to make their communication successful through use of the most salient and mutually intelligible linguistic forms, which subsequently propagate throughout the speech community. One common diagnostic feature of such a stage is expression of tense/aspect markers lexically-not morphologically-through temporal adverbials or to rely on pragmatic/contextual hints to express such notions. As has been shown in PM, RPA, and GPA, tense/aspect markers are expressed lexically through adverbials or inferred from the context. This is also in tandem with Versteegh's (2016) study of the earliest stages of JA and KiNubi Arabic creole, where he finds that these contact varieties did not have any grammaticalized aspectual markers. There are several reasons, which have given rise to selecting lexical tense/aspect markers in contact setting. First, there is growing evidence that content words and free morphemes tend to be acquired before other bound morphemes due to their higher perceptual saliency (Craats et al., 2000; DeGraff, 1999). Siegel (2008), for instance, states that children acquiring their L1, adults, and speakers with a language impairment in the earliest stages of learning L2 often miss production of 
inflections and grammatical morphemes because these features are hard to perceive (Bates \& Goodman, 1999). Second, one processing difference between morphologically free morphemes and bound morphemes is that the former is easily identified due to the transparent word-meaning mapping. On the other hand, bound morphemes are more difficult to detect because the boundaries between morphemes are hard to perceive in the speech chain. This observation is in line with Mufwene's (1991) argument that periphrastic structures (or analytic markers) are more salient in language contact situations than are morphologically bound structures because of the transparency inherent in the semantics of these constructions. Moreover, Clement's (2014, pp. 382-383) notion of detectability in language contact situations indicates, "Free-standing morphemes are more detectable than clitics and affixes." All in all, the preference for lexical tense/aspect markers rather than morphological components in the early stages of pidgin formation makes clear the inherent characteristics in those structures. In later developmental stages, however, like JA and TP, which are considered stabilized pidgins, tense/aspect systems of increased sophistication gradually develop.

\section{Conclusion}

This study examined the development of tense/aspect in five Arabic-based pidgins: JA, TP, PM, RAP, and GPA. Using Siegel (2008) scale of morphological simplicity, from lexicality to grammaticality, this study concludes that tense/aspect marking is expressed lexically through temporal adverbials or inferred from the context in the earliest stages of Arabic-based pidgins, which only later-in stabilized pidgins-develops into grammaticalized markers when certain criteria are met. The current study contributes to the existing literature in that tense/aspect can be expressed by other means in the early stages of developing a communal language, i.e., temporal adverbials. As soon as this communal language develops, such grammatical tools develop into obligatory grammatical items, clitics, or inflectional suffixes.

As evident in PM, RPA, and GPA, the findings of the current study emphasize the notion that tense/aspect marking in the earliest stages of Arabic-based pidgins is compatible with the consensus notion that tense/aspect 
markers are expressed lexically through adverbials or conveyed pragmatically through context. Only later do stabilized Arabic-based pidgins, such as JA and TP, develop unique tense/aspect markers. In other words, tense/aspect markers have become grammaticalized from which the pragmatic context minimally benefits in producing an understanding of the utterances. The development of a more complex system for expressing tense/aspect in a given contact variety can be ascribed to stability, which might be increased or decreased among other things, by the relative contact among members of the speech community, their social hierarchies, their movement opportunities, and their attitudes towards this kind of contact variety. Although the varieties surveyed in this study represent various developmental stages, excluding Arabic creole from this examination is one of the limitations of this study. One prominent contribution of this study is its proposal of a preference for free morphemes rather than bound morphemes to express tense/aspect marking in the earliest stages of Arabic-based pidgins. In proposing thusly, I must emphasize the need for new research, both synchronic and diachronic, on Arabic-based pidgins' use in avenues that have been studied minimally if at all and on their sociohistory. Studies may include the development of inflectional and derivational morphology and reduction strategies employed.

\section{References}

Aartun, K. (1963). Zur Frage altarabischer Tempora. Oslo Universitetsforlag. Abd-el-Jawad, R. (1992). Is Arabic a pluricentric language? In M. Clyne (Ed.), Pluricentric languages (pp. 261-304). Mouton de Gruyter.

Al Wer, E. (2002). Education as a speaker variable. In A. Rouchdy (Ed.), Language contact and language conflict in Arabic: Variations on a sociolinguistic theme (pp. 41-53). Routledge Curzon.

Al-Azraqi, M. (2020). Pidginisation in Abha, Saudi Arabia: Pathways to multifunctionality. Journal of Pidgin and Creole Languages, 23(1), 3761.

Alghamdi, E. (2014). Gulf Pidgin Arabic: A descriptive and statistical analysis of stability. International Journal of Linguistics, 6(6), 110-127.

Al-Mansouri, A. J. (2002). Ad-dalaala az-zamaniyya fi-l-žumla al-Sarabiyya. 


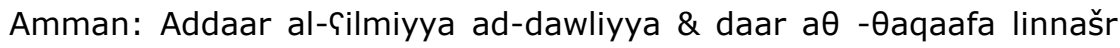
wattawziic.

Almoaily, M. (2012). Language variation in Gulf Pidgin Arabic. Doctoral dissertation. Newcastle University, Newcastle, UK.

Alshammari, W. (2018). The development of and accommodation in Gulf Pidgin Arabic. Doctoral dissertation. Indiana University-Bloomington, Bloomington, IN.

Ansaldo, U., \& Matthews, S. (2007). Deconstructing creole: The rationale. In U. Ansaldo, S. Matthews, \& L. Lim (Eds.), Deconstructing creole (pp. 118). John Benjamin Company.

Avram, A. (2010). An outline of Romanian Pidgin Arabic. Journal of Language Contact-VARIA, 3, 20-38.

Avram, A. (2011). Pseudo-reduplication, reduplication and repetition: The case of Arabic-lexified pidgins and creoles. $R R L, 56(3), 225-256$.

Avram, A. (2019). Africanisms in Turku. In C. Miller, A. Barontini, M. Germanos, J. Guerrero, \& C. Pereira (Eds.), Studies on Arabic dialectology and sociolinguistics (pp. 15-240). Proceedings of the $12^{\text {th }}$ conference of AIDA held in Marseille from May 30th to June $2^{\text {nd }}, 2017$.

Avram, A. (2020). Arabic pidgins and creoles. In C. Lucas, \& S. Manfredi (Eds.), Arabic and contact-induced change (pp. 321-347). Language Science Press.

Bache, C. (1985). Verbal aspect: A general theory and its application to present-day English. Odense University Press.

Bahloul, M. (2008). Structure and function of the Arabic verb. Routledge.

Bakir, M. (2010). Notes on the verbal system of Gulf Pidgin Arabic. Journal of Pidgin and Creole Languages, 25(2), 201-228.

Bakir, M. (2014). The multifunctionality of fii in Gulf Pidgin Arabic. Journal of Pidgin and Creole Languages, 29(2), 410-436.

Bakker, P. (1994). Pidgins. In J. Arends, P. Muysken, \& N. Smith (Eds.), Pidgins and Creoles: An introduction (pp. 25-39). John Benjamins Publishing Company.

Bakker, P., \& Mühlhäusler, P. (1990). From business to pidgin. Journal of Asian Pacific Communication, 1, 87-115.

Bakker, P., Post, M., \& Voort, H. (1994). TMA particules and auxiliaries. In 
J. Arends, P. Muysken, \& N. Smith (Eds.), Pidgins and Creoles: An introduction (pp. 247-258). John Benjamins Publishing Company.

Bates, E., \& Goodman, J. (1999). On the emergence of grammar from the lexicon. In B. Macwhinney (Ed.), The emergence of language (pp. 29-80). LEA.

Beeston, A. F. (1970). The Arabic language today. Hutchinson.

Benazzo, S. (2003). The interaction between verb morphology and temporal adverbs of contrast. A longitudinal study in French, English and German L2. In C. Dimroth, \& M. Starren (Eds.), Information structure and the dynamics of language acquisition (pp. 187-210). Benjamins.

Benazzo, S., \& Starren, M. (2007). L'émergence de moyens grammaticaux pour exprimer les relations temporelles en L2. Acquisition et interaction en langue étrangère, 25, 129-157.

Bickerton, D. (1974). Creolization, linguistic universals, natural semantax and the brain. Working Papers in Linguistics, 6(3), 124-41.

Bizri, F. (2009). Sinhala in contact with Arabic: The birth of a new pidgin in the Middle East. ARSALL, 135-148.

Bizri, F. (2010). Pidgin Madame. Une grammaire de la servitude. Geuthner.

Clements, J. C. (2009). The legacy of Spanish and Portuguese: Colonial expansion and language change. Cambridge University Press.

Clements, J. C. (2014). Form selection in contact languages: Evidence from Portuguese and Spanish-lexified contact varieties. In P. Amaral, \& A. Carvalho (Eds.), Portuguese/Spanish interfaces (pp. 377-401). John Benjamins.

Comrie, B. (1976). Aspect. Cambridge University Press.

Comrie, B. (1985). Tense. Cambridge University Press.

Craats, Van de., I., Corver, N., \& Van Hout, R. (2000). Conservation of grammatical knowledge: On the acquisition of possessive noun phrases by Turkish and Moroccan learners of Dutch. Linguistics, 38(2), 221314.

DeGraff, M. (1999). Creolization, language change, and language acquisition: An epilogue. In M. DeGraff (Ed.), Language creation and language change: Creolization, diachrony, and development (pp. 473-543). MIT Press. 
Fayer, J. (1990). Nigerian Pidgin English in Old Calabar in the eighteenth and nineteenth centuries In J. Singler (Ed.), Pidgin and creole: Tensemood-aspect systems (pp. 185-202). John Benjamins.

Foley, W. (1988). Language birth: The processes of pidginisation and creolization. In F. Newmeyer (Ed.), Linguistics: The Cambridge survey (pp. 162-183). Cambridge University Press.

Foley, W. (2013). Yimas-Arafundi pidgin. In P. Bakker, M. Haspelmath, \& S. Michaelis (Eds.), Survey of pidgin and creole languages 4 (pp. 105113). Oxford University Press.

Givón, T. (1998). The functional approach to grammar. In M. Tomasello (Ed.), The new psychology of language: Cognitive and functional approaches to language structure (pp. 203-219). Lawrance Erlbaum Associates.

Goddard, I. (1996). Pidgin Delaware. In S. G. Thomason (Ed.), Contact languages, a wider perspective (pp. 43-124). John Benjamins.

Grant, A. (2013). Chinuk Wawa. In S. Michaelis, P. Maurer, M. Haspelmath, \& M. Huber (Eds.), The survey of pidgin and creole languages, Vol. III: Contact languages based on languages from Africa, Australia and the Americas (pp. 149-157). Oxford University Press.

Holm, J. (1988). Pidgins and creoles: Theory and structure. Cambridge University Press.

Holm, J. (1989). Pidgins and creoles: 2, Reference survey. Cambridge University Press.

Holm, J. (2000). An introduction to pidgins and creoles. Cambridge University Press.

Holm, J. (2004). An introduction to pidgins and creoles. Cambridge University Press.

Hopper, P., \& Traugott, E. (1993). Grammaticalization. Cambridge University Press. http://www.urduword.com/search.php?Naskh=بادمين

Klein, W., \& Perdue, C. (1997). The basic variety: Or couldn't natural languages be much simpler? Second Language Research, 13, 301-347.

Labov, W. (1990). On the adequacy of natural languages: I. The development of tense. In J. Singler (Ed.), Pidgin and creole tense/mood/aspect systems (pp. 1-58). John Benjamins.

Mahmud, U. (1979). Variation in the aspectual system of Juba Arabic. Doctoral 
dissertation. Georgetown University, Washington, D.C.

Mahmud, U. (1982). Arabic in the Southern Sudan. FAL.

Manfredi, S. (2017). Arabi Juba: Un pidgin-créole du Soudan du Sud. Peeters. Manfredi, S., \& Petrollino, S. (2013). Juba Arabic. In S. M. Michaelis, P. Maurer, M. Haspelmath, \& M. Huber (Eds.), Contact languages based on languages from Africa, Asia, Australia, and the Americas (pp. 54-66). Oxford University Press.

Miller, C. (2002). The relevance of Arabic-based pidgin/creoles for Arabic linguistics. In G. Mansour, \& M. Doss (Eds.), al-Lugha (pp. 7-46). Arab Development Center.

Miller, C. (2003). Reduplication in Arabic-based contact languages. In S. Kouwenberg (Ed.), Twice as Meaningful. Reduplication in pidgins, creoles and other contact languages (pp. 289-299). Battlebridge Publications.

Mowarin, M. (2008). Tense, mood and aspect in Nigerian pidgin. Language Forum: A Journal of Language and Literature, 34(2), 71-86.

Mufwene, S. (1991). Pidgins, creoles, typology, and markedness. In F. Byrne, \& T. Huebner (Eds.), Development and structures of creole languages: Essays in honor of Derek Bickerton (pp. 123-43). John Benjamins.

Mufwene, S. (1997). Jargons, pidgins, creoles, and koines: What are they? In S. Arthur, \& W. Donald (Eds.), The Structure and status of pidgins and creoles (pp. 35-69). John Benjamins.

Mühlhäusler, P. (1986). Pidgin and creole linguistics. Blackwell.

Mühlhäusler, P. (1997). Pidgin and creole linguistics, $2^{\text {nd }}$ ed. University of Westminster Press.

Muysken, P. (1981). Creole tense/mood/aspect systems: The unmarked case? In P. Muysken (Ed.), Generative studies on creole language (pp. 18199). Foris.

Muysken, P., \& Smith, N. (1994). The study of pidgin and creole languages. In J. Arends, P. Muysken, \& N. Smith (Eds.), Pidgins and creoles: An introduction (pp. 3-14). John Benjamins.

Naess, U. (2008). Gulf pidgin Arabic: Individual strategies or a structured variety? Master's thesis. University of Oslo, Norway.

Owens, J. (2018). Arabic historical dialectology: Linguistic and sociolinguistic 
approaches. In C. Holes (Ed.), Dialects (Speech Communities), The apparent past, and grammaticalization: Towards an understanding of the history of Arabic (pp. 206-256). Oxford University Press.

Parkvall, M., \& Bakker, P. (2013). Pidgins. In P. Bakker, \& M. Yaron (Eds.), Contact languages: A comprehensive guide (pp. 15-64). Walter de Gruyter.

Sebba, M. (1997). Contact languages. Palgrave Publishers Ltd.

Siegel, J. (2008). The emergence of pidgin and creole languages. Oxford University Press.

Singler, J. (1990). Introduction: Pidgins and creoles and tense-mood-aspect. In J. Singler (Ed.), Pidgin and creole tense/mood/aspect systems (pp. 7-16). John Benjamins.

Singler, J. (1992). The sources of substratal input into French-lexifier creole in the Caribbean in the seventeenth century: Some demographic evidence. Paper presented at the Ninth Biennial Meeting of the Society of the Caribbean Linguistics, Cave Hills, Barbados.

Singler, J. (1996). Theories of creole genesis, sociohistorical considerations, and the evaluation of evidence: The case of Haitian Creole and the relexification hypothesis. Journal of Pidgin and Creole Languages, 11(2), 185-230.

Smith, H. (2013). Habitual aspect marking in Palenquero: Varition in present temporal reference. In A. M. Carvalho, \& S. Beaudrie (Eds.), Selected proceedings of the $6^{\text {th }}$ workshop on Spanish sociolinguistics (pp. 97108). Cascadilla Proceedings Project.

Thomason, S. (2008). Pidgins/creoles and historical linguistics. In S. Kouwenberg, \& J. Singler (Eds.), The handbook of pidgin and creole studies (pp. 242-262). Wiley-Blackwell.

Thomason, S., \& Kaufman, T. (1988). Language contact, creolization, and genetic linguistics. University of California Press.

Tosco, M., \& Manfredi, S. (2013). Pidgins and creoles. In J. Owens (Ed.), The oxford handbook of Arabic linguistics (pp. 495-519). Oxford University Press.

Tosco, M., \& Owens, J. (1993). Turku: A descriptive comparative study. Sprache und Geschichte in Afrika, 14, 177-267. 
Tosco, M. (1995). A pidgin verbal system: The case of Juba Arabic. Anthropological Linguistics, 37(4), 423-459.

Velupillai, V. (2015). Pidgins, creoles and mixed languages: An introduction. John Benjamins.

Versteegh, K. (2014). Speaking of the past: The development of past time reference in Arabic pidgins. In S. Manfredi, \& M. Tosco (Eds.), Arabicbased pidgins and creoles (pp. 211-231). John Benjamins.

Versteegh, K. (2016). Aspect marking in Juba Arabic and Ki-Nubi. In M. Sartori, M. E. B. Giolfo, \& P. Cassuto (Eds.), Approaches to the history and dialectology of Arabic in honor of Pierre Larcher (pp. 451-473). Brill.

Versteegh, K. (2018). Temporal adverbs of contrast in the Basic Variety of Arabic. In S. Manfredi, \& M. Tosco (Eds.), Arabic in contact (pp. 233250). John Benjamins.

Versteegh, K. (2020). Time and tense in basic varieties of Arabic. In Z. A. Taha (Ed.), Revisiting levels of contemporary Arabic: Essays on Arabic varieties in memory of El-Said Badawi (pp. 41-54). American University in Cairo Press.

Voort, H. (1994). Eskimo pidgin. In J. Arends, P. Muysken, \& N. Smith (Eds.), Pidgins and creoles: An introduction (pp. 137-151). John Benjamins.

Wardhaugh, R. (2010). An introduction to sociolinguistics. MA.

Whinnom, K. (1971). Linguistic hybridization and the "special case" of pidgin and creoles. In D. Hymes (Ed.), Pidginization and creolization of languages (pp. 91-115). Cambridge University Press. 


\section{Wafi Fhaid Alshammari}

Hailo (Ha'il) universitetas, Saudo Arabija; wf.alshammari@uoh.edu.sa

\section{LAIKO (VEIKSLO) ŽYMĖJIMAS ARABU KALBOS PAGRINDU SUSIFORMAVUSIUOSE PIDŽINUOSE}

Santrauka. Ankstyviausiuose pidžino formavimosi etapuose pirmenybė teikiama analitinèms ir morfologiškai redukuotoms gramatinèms konstrukcijoms, palyginti su ju pagrindinèmis arba substratinèmis kalbomis, kuriose akivaizdus morfologinis žymèjimas, jei jis ir aptinkamas, atrodo sustabarèjęs. Todèl struktūriniai santykiai dažniausiai išreiškiami išoriškai. Laiko (veikslo) kategorijos žymimos laiko prieveiksmiais arba numanomos iš konteksto. Tačiau teigiama, kad kreolu kalbos tokias kategorijas sukuria gramatizuodamos. Šiame tyrime nagrinèjamas laiko (veikslo) žymejjimas penkiuose arabu kalba grindžiamuose pidžinuose: Juba, Turku, Madame, Romanian ir Gulf. Remiantis Siegel (2008) morfologinio paprastumo skale nuo leksiškumo iki gramatiškumo, šiame tyrime daroma išvada, kad ankstyviausiuose arabu pidžinu etapuose laiko (veikslo) žymèjimas išreiškiamas leksiškai laiko prieveiksmiais arba išvedamas iš konteksto, o tik vèliau - nusistovejjusiuose pidžinuose - virsta gramatiniais žymenimis, kai atitinkami tam tikri kriterijai.

Pagrindinès sąvokos: arabu kalbos pagrindu susiformavę pidžinai; veikslas; leksiniai žymenys; laikas. 